\title{
Phenotypic and genetic associations of milk traits with milk coagulation properties
}

\author{
N. A. Poulsen, ${ }^{* 1}$ A. J. Buitenhuis, $†$ and L. B. Larsen* \\ ${ }^{*}$ Department of Food Science, Science and Technology, and \\ †Department of Molecular Biology and Genetics, Science and Technology, Aarhus University, Blichers Allé 20, PO Box 50, DK-8830 Tjele, \\ Denmark
}

\section{ABSTRACT}

The aim of this study was to examine milk composition and rennet-induced coagulation properties of milk from 892 individual Danish Holstein and Danish Jersey cows and determine the genetic influences on these properties by determining heritability and genomic correlations with single nucleotide polymorphisms identified by the bovine HD Beadchip (Illumina Inc., San Diego, CA). Despite no signs of clinical mastitis, milk from cows with somatic cell counts $>500,000$ cells $/ \mathrm{mL}$ showed altered milk composition, indicating impaired barrier between the milk and the blood. Curd-firming rate $(\mathrm{CFR})$ and rennet coagulation time $(\mathrm{RCT})$ were used to describe milk coagulation properties (MCP). These traits describe the second phase of milk coagulation and were mutually negatively correlated, but only to some extent associated with the same compositional traits. In both breeds, CFR were highly correlated with protein content, whereas longer RCT were primarily associated with lower milk pH. Estimated heritabilities for milk production and compositional traits ranged from 0.09 for yield to 0.82 for citric acid in Danish Jersey cows, and from 0.21 for yield to 0.59 for citric acid in Danish Holstein cows. Heritabilities for MCP traits varied considerably between breeds, and were estimated to be 0.28 for RCT and 0.75 for CFR in Danish Holstein cows and 0.45 for RCT and 0.15 for CFR in Danish Jersey cows. This difference was further reflected in the genomic correlations between $\mathrm{RCT}$ and CFR which was -0.90 in Danish Holstein and 0.06 in Danish Jersey. These data suggest that potential for changing MCP through breeding exists, but the genetic background of the MCP traits might be different in different breeds; therefore, using Danish Holstein as background for Danish Jersey is not trivial. Thereby, the study underlines the need for breed-specific models.

Received January 14, 2014.

Accepted January 2, 2015.

${ }^{1}$ Corresponding author: Nina.Poulsen@agrsci.dk
Key words: coagulation, genomic heritability, genomic correlation, somatic cell count

\section{INTRODUCTION}

Genetic and environmental factors affect raw milk quality and cause variations in nutritional and functional properties of milk within and among cow breeds. Moreover, the physiological state and health of cows affect milk composition, and milk from individual cows measured at different times during lactation can vary notably (Palmquist et al., 1993; Jõudu et al., 2007).

Rennet-induced milk coagulation is central to the initial phases of cheese manufacturing. In Denmark, $47 \%$ of milk is used for cheese production (Danish Agricultural and Food Council, 2012), and improved cheese milk is therefore of interest to industry. Variation in milk coagulation properties (MCP) among individual cows is primarily related to the quantities and relative proportions of caseins $\left(\alpha_{\mathrm{S1}^{-}}, \alpha_{\mathrm{S}^{-}}, \beta-\right.$, and $\left.\kappa-\mathrm{CN}\right)$ and whey proteins (Jõudu et al., 2008), and the distribution of micellar and soluble minerals, especially calcium and phosphorus (Hallén et al., 2010; Jensen et al., 2012). These components influence the size and stability of casein micelles. For example, high levels of $\kappa-\mathrm{CN}$ are associated with smaller micelles, and high calcium content leads to increased micellar-bound $\mathrm{CN}$, which increases cheese yield (Gaucheron, 2005; Glantz et al., 2010a). Posttranslational modifications of $\mathrm{CN}$ also play roles, and more heavily phosphorylated proteins are associated with poor coagulation (Frederiksen et al., 2011; Jensen et al., 2012), whereas a higher proportion of glycosylated $\kappa$-CN seems to be associated with shorter rennet coagulation times (RCT; Bonfatti et al., 2014).

Another important factor that determines milk coagulation is milk $\mathrm{pH}$. Acidification of milk initiates aggregation of $\mathrm{CN}$ micelles. By adding starter cultures to milk, cheese producers can ensure better cheese yield and provide the $\mathrm{pH}$ needed for optimal rennet activity. Altered $\mathrm{pH}$ levels in raw milk from individual cows can reflect mastitis, where an impaired barrier between blood and milk raises milk $\mathrm{pH}$ toward the higher $\mathrm{pH}$ of 
the blood. Lower milk pH induces dissolution of micellar calcium phosphate (Gaucheron, 2005) and thereby influences the MCP. In addition to $\mathrm{pH}$, milk constituents with chelating activities can decrease micellarbound calcium (Gaucheron, 2005). For example, citrate in milk can form salts with calcium, which reduces the stability of CN micelles, and increased citrate levels in skim milk from individual cows has previously been associated with poor MCP (Frederiksen et al., 2011; Sundekilde et al., 2011). Moreover, clinical and subclinical mastitis and secretions of constituents from blood or interstitial fluids through the paracellular pathway can impair milk quality by changing milk composition (Shennan and Peaker, 2000).

Several studies have documented reasonable heritabilities for milk production, quality, and coagulation traits. According to a recent review by Bittante et al. (2012), the estimated heritabilities for RCT and curd firmness across cow populations were 0.26 and 0.27 , respectively. Generally, heritability estimates for curd firmness vary more than for RCT, and its variation is more prone to the analytic method used in the study, the rennet concentration, or differences in statistical models used (Bittante et al., 2012). The moderate to large heritabilities for MCP traits suggested that they are genetically regulated and may be included in future breeding objectives.

Previously, we have demonstrated differences in the MCP of milk from 3 Scandinavian cow breeds and documented strong associations with major genetic variants of the CN genes (Poulsen et al., 2013). The objective of the present study was to investigate the associations between milk composition traits and MCP on pH-normalized milk from healthy, mid lactation Danish Holstein (DH) and Danish Jersey (DJ) cows and estimate heritability for these traits as well as the genomic correlations between them.

\section{MATERIALS AND METHODS}

\section{Samples}

Our study was conducted as part of the DanishSwedish Milk Genomics Initiative. Ear tissue and morning milk samples were collected from $456 \mathrm{DH}$ cows from 20 dairy herds (October-December 2009) and 436 DJ cows from 22 dairy herds (February-April 2010) in mid lactation. Care was taken to minimize potential sources of environmental variation and to ensure low genetic relatedness among cows in the sample populations. Samples were collected at 1 morning milking, and all cows were from conventional (nonorganic) herds. All cows were housed in loose housing systems, fed accord- ing to standard practices, and milked 2 or, rarely, 3 times daily (see also Poulsen et al., 2012). Parity and lactation stage were recorded for all cows. Milk yield at each milking was recorded, and representative milk samples were at least $0.5 \mathrm{~L}$. Samples were placed on ice during transport to the laboratory.

Individual milk samples were analyzed for SCC using flow cytometry (Fossomatic 5000, Foss Analytical, Hillerød, Denmark) at the Eurofins Laboratory (Holstebro, Denmark). Milk samples were also analyzed for fat, protein, lactose, CN, citric acid, and urea content by infrared spectroscopy (MilkoScan FT2, Foss Analytical).

In addition to infrared measurements, $\mathrm{pH}$ and conductivity were measured in skim milk samples, before coagulation, with a PHM $220 \mathrm{pH}$ meter (RadioMeter, Copenhagen, Denmark) and an LDM 210 conductivity meter (RadioMeter). Immediately after sampling, milk samples were aliquoted, skimmed (centrifuged for 30 min at $2,643 \times g$ at $4^{\circ} \mathrm{C}$ ), and refrigerated at $5^{\circ} \mathrm{C}$ for up to $6 \mathrm{~h}$ without preservatives before rheological analyses.

\section{Rheological Analyses for Determination of MCP}

Rennet-induced coagulation of skim milk samples was determined by a ReoRox4 rheometer (MediRox AB, Nyköping, Sweden), as outlined in Poulsen et al. (2013). Briefly, milk samples were adjusted to $\mathrm{pH} 6.5$ with $10 \%$ (vol/vol) lactic acid and preincubated for 30 min at $33^{\circ} \mathrm{C}$ before the rheological analysis. Hereafter, each milk sample was set into free oscillation and amplitude damping and frequency changes were measured continuously for $1 \mathrm{~h}$ after addition of chymosin to a final concentration of 0.04 international milk clotting units (IMCU) per mL. Each milk sample was measured as technical duplicates. The MCP for individual samples were described as RCT and curd-firming rate (CFR) with the ReoRox software (version 1.5.0.1055). The RCT was defined as the amount of time from chymosin addition to when the phase angle reached $45^{\circ}\left(\theta=45^{\circ}\right)$; $\mathrm{CFR}$ was calculated from consecutive points of the linear (lin) part of the gelation profile $\left[\Delta \mathrm{G}^{\prime} / \Delta \mathrm{t}\right]_{\text {lin }}$, where $\mathrm{G}^{\prime}$ is the storage modulus and $\mathrm{t}$ is time in minutes.

\section{SNP Markers and Genotyping}

Genomic DNA extracted from ear tissue resulted in total, $371 \mathrm{DH}$ and $302 \mathrm{DJ}$ cows that were genotyped by the bovine HD Beadchip (Illumina Inc., San Diego, CA; Van Tassell et al., 2008). From these animals, 777,962 SNP markers were assayed, with a median interval of $2.68 \mathrm{~kb}$ between SNP (www.illumina.com). The Illumina Infinium II Multisample assay platform was used. The SNP chips were scanned by iScan and analyzed with 
the Beadstudio v. 3.1 software (Illumina). The quality parameters used to select SNP had minimum call rates of $80 \%$ for individuals and $95 \%$ for loci. Marker loci with minor allele frequencies below $1 \%$ were excluded. The minimal acceptable GenCall score (Teo et al., 2007) was 0.65 for individual typing, and individuals with average GenCall scores below 0.65 were excluded. A total of 588,528 SNP spread over BTA1-BTA29 were used in the analyses; SNP positions within chromosomes were based on the Bos taurus genome assembly (Btau_4.0, Liu et al., 2009).

\section{Statistical Analyses}

Prior to statistical analyses, cows that produced noncoagulating milk were removed from the data $(\mathrm{DH}$ : 21 cows; DJ: 2 cows). Cows that produced coagulating milk were divided into a low and a high group based on whether SCC was below or above 500,000 cells $/ \mathrm{mL}$, respectively, for each breed. The difference between the high and low group within a breed was assessed by a Wilcoxon rank sum test, which was also applied to compare the low-cell count group from $\mathrm{DH}$ with the low-cell count group of DJ cows. The CFR and RCT in low-cell count groups from DH and DJ were further examined using multiple linear regression within each breed. The model contained the fixed effect of parity (group 1: parity 1, group 2: parity 2 and 3) and stage of lactation (mid lactation 1: d 126-157, mid lactation 2: d 158-189, mid lactation 3: d 190-220, mid lactation 4: d 221-252). Contents of protein, fat, lactose, citric acid, and urea were included in the model together with $\mathrm{pH}$, conductivity, and actual yield. Estimates of genetic parameters were based on phenotypic and genotypic information from $357 \mathrm{DH}$ and 302 DJ cows.

The genomic relationship matrix was described in detail by Buitenhuis et al. (2013). In short, a genomic relationship matrix was calculated for each chromosome separately, as described first by VanRaden (2008). Briefly, let $\mathbf{M}$ be a matrix with dimensions of the number of individuals $(n)$ by the number of loci $(m)$ that specifies which marker alleles each individual inherited. The elements of $\mathbf{M}$ were set to $-1,0$, or 1 for homozygote, heterozygote, and other homozygote genotypes, respectively. The diagonals of $\mathbf{M}^{\prime} \mathbf{M}$ count the number of homozygous loci for each individual, and the off diagonals measure the relative number of alleles shared by relatives. Let the frequency of the second allele at locus $i$ be $p_{i}$, and let $\mathbf{P}$ contain the allele frequencies, such that column $i$ of $\mathbf{P}$ equals $2\left(p_{i}-0.5\right)$. Subtraction of $\mathbf{P}$ from $\mathbf{M}$ gives $\mathbf{Z}$, which is needed to set the expected mean value to 0 . The genomic relationship matrix $\mathbf{G}$ is $\mathbf{Z Z} \mathbf{Z}^{\prime} /\left[2 \Sigma p_{i}\left(1-p_{i}\right)\right]$ (VanRaden, 2008).

\section{Estimation of Heritability}

To estimate the genetic parameters and variance components, the REML approach in DMU (Madsen and Jensen, 2007) was used. The following model was used in the analysis:

$$
\begin{aligned}
\mathrm{Y}_{\mathrm{ijklm}}= & \mu+\operatorname{herd}_{\mathrm{i}}+\operatorname{parity}_{\mathrm{j}}+\operatorname{DIM}_{\mathrm{k}} \\
& +\operatorname{animal}_{l}+\mathrm{e}_{\mathrm{ijklm}},
\end{aligned}
$$

where $Y_{i j k l m}$ is the phenotype of animal $m$ in herd $i$, lactation $\mathrm{j}$, and DIM $\mathrm{k} ; \mu$ is the fixed mean effect; herd is a fixed effect $(\mathrm{i}=1,2, \ldots, 20)$; parity is a fixed effect $(\mathrm{j}=1,2,3)$; animal is a random additive genetic effect based on the $\mathbf{G}$ of animal $\mathrm{l}$; and $\mathrm{e}_{\mathrm{ijklm}}$ is the random residual effect.

Univariate analyses were performed to estimate the heritability, which was defined as

$$
\mathrm{h}^{2}=\sigma_{a}^{2} /\left(\sigma_{a}^{2}+\sigma_{e}^{2}\right)
$$

where $\sigma_{a}^{2}$ was the genetic variation and $\sigma_{e}^{2}$ was the residual variation. Genetic and phenotypic correlations were studied by fitting a series of bivariate analyses with the REML approaches in DMU (Madsen and Jensen, 2007).

\section{RESULTS}

\section{Milk Composition Changes Associated with High SCC}

None of the cows included in the study showed visual signs of mastitis. All of the milk analyzed would normally have been transferred to the bulk tank. However, $8 \%$ of DH and $6 \%$ of the DJ cows analyzed had SCC above 500,000 cells $/ \mathrm{mL}$. Several milk composition traits in both breeds varied significantly in milk samples with high compared with low SCC (Table 1). High SCC was associated with higher parity, $\mathrm{pH}$, and conductivity, but lower lactose content. The DH cows with higher SCC had significantly lower milk yields, but higher total protein and fat contents. Conversely, DJ cows with high SCC had longer RCT and lower CFR. In addition to differences within breeds, the low-SCC groups from DH and DJ were statistically different in yield and all milk compositional traits measured, consistent with previous data shown by Poulsen et al. (2012).

\section{Phenotypic Correlations}

The RCT and CFR were negatively correlated in both breeds (Figure 1). Pearson correlation coefficient 
Table 1. Comparison of milk with high $(>500,000$ cells $/ \mathrm{mL})$ and low $(<500,000$ cells $/ \mathrm{mL})$ SCC from Danish Holstein (DH) and Danish Jersey (DJ) $\operatorname{cows}^{1}$

\begin{tabular}{|c|c|c|c|c|c|c|c|}
\hline Item & \multicolumn{3}{|c|}{$\mathrm{DH}$} & \multicolumn{3}{|c|}{ DJ } & Effect \\
\hline Parity & $1.71 \pm 0.76$ & $2.11 \pm 0.76$ & $* *$ & $1.7 \pm 0.77$ & $2.2 \pm 0.82$ & $* *$ & $\uparrow$ \\
\hline DIM & $179 \pm 21$ & $184 \pm 23$ & NS & $186 \pm 23$ & $182 \pm 22$ & NS & - \\
\hline Yield $(\mathrm{kg})$ & $14.75 \pm 3.81$ & $12.64 \pm 3.42$ & $* *$ & $10.16 \pm 2.56$ & $9.33 \pm 3.50$ & NS & $\downarrow$ \\
\hline $\begin{array}{l}\text { Curd-firming rate }(\mathrm{Pa} / \\
\min )\end{array}$ & $8.97 \pm 4.18$ & $8.59 \pm 4.22$ & NS & $21.65 \pm 6.65$ & $18.60 \pm 6.36$ & NS & - \\
\hline Protein $(\mathrm{g} / 100 \mathrm{~g}$ of milk) & $3.43 \pm 0.25$ & $3.60 \pm 0.32$ & $* *$ & $4.31 \pm 0.32$ & $4.26 \pm 0.27$ & NS & $\uparrow$ \\
\hline Fat $(\mathrm{g} / 100 \mathrm{~g}$ of milk $)$ & $4.00 \pm 0.78$ & $4.30 \pm 1.05$ & $*$ & $5.99 \pm 0.86$ & $5.88 \pm 0.82$ & NS & $\uparrow$ \\
\hline Lactose ( $\mathrm{g} / 100 \mathrm{~g}$ of milk) & $4.79 \pm 0.13$ & $4.66 \pm 0.15$ & $* * *$ & $4.63 \pm 0.14$ & $4.46 \pm 0.22$ & *** & $\downarrow$ \\
\hline Conductivity $(\mathrm{mS} / \mathrm{cm})$ & $5.82 \pm 0.41$ & $6.08 \pm 0.40$ & $* * *$ & $5.43 \pm 0.40$ & $5.73 \pm 0.62$ & $* *$ & $\uparrow$ \\
\hline Urea $(\mathrm{m} M)$ & $210.2 \pm 61.6$ & $213.3 \pm 62.9$ & NS & $272.8 \pm 59.7$ & $284 \pm 66.85$ & NS & - \\
\hline
\end{tabular}

${ }^{1}$ Arrows indicate significantly lower or higher values for different items in the high-SCC group than in the low-SCC group in one or both breeds. ${ }^{*} P<0.05,{ }^{* *} P<0.01,{ }^{* * *} P<0.001$.

was $-0.59\left(\mathrm{R}^{2}=0.35, P<0.001\right)$ for $\mathrm{DH}$ and -0.46 $\left(\mathrm{R}^{2}=0.21, P<0.001\right)$ for DJ. However, as depicted in Figure 1, the relationship between RCT and CFR fit a second-order polynomial regression model better than a linear model, thereby increasing $\mathrm{R}^{2}$ to 0.44 and 0.27 for DH and DJ, respectively. Variations in coagulation traits among individual cows were generally larger in DH compared with DJ, as reflected by the coefficients of variation (0.47 in $\mathrm{DH}$ and 0.30 in $\mathrm{DJ}$ for CFR, 0.20 in $\mathrm{DH}$ and 0.15 in $\mathrm{DJ}$ for RCT).

Multiple linear regression models for CFR and RCT showed that parity and stage of lactation affected CFR and RCT significantly. Cows in parity 2 and 3 had higher CFR in both breeds as well as significantly shorter RCT in DJ. The mid lactation class 3 had improved milk coagulation with higher $\mathrm{CFR}$ in $\mathrm{DH}$ and shorter RCT in DH and DJ, whereas the mid lactation class 4 in DJ had longer RCT compared with mid lactation class 3 (Table 2). Generally, milk composition traits only explained a low proportion of the variation in CFR $\left(\mathrm{R}^{2}=0.30\right.$ in $\mathrm{DH}$ and 0.34 in $\left.\mathrm{DJ}\right)$ and $\mathrm{RCT}$ $\left(\mathrm{R}^{2}=0.07\right.$ in $\mathrm{DH}$ and 0.18 in DJ. In particular, protein content influenced CFR, but lactose, citric acid, and $\mathrm{pH}$ also positively affected CFR in DJ, but not significantly in $\mathrm{DH}$.

For RCT, an increasing $\mathrm{pH}$ was related to shorter RCT in both breeds, but also increasing contents of citric acid and lactose were associated with shorter RCT in DJ cows. Furthermore, protein and urea contents positively affected RCT in DJ.

\section{Genomic Correlations and Heritability}

Heritability estimates based on the genomic relationship matrix were moderate to high, ranging from 0.09 for yield in DJ to 0.82 for citric acid in DJ (Table $3)$. Standard errors ranged from 0.16 to 0.35 . The DJ had higher heritabilities for 7 of the 11 traits analyzed. In particular, the heritabilities for urea and citric acid were very high, 0.80 and 0.82 , respectively, in DJ cows. The CFR had relatively low heritability in DJ cows (0.15) compared with the high heritability in $\mathrm{DH}$ cows (0.75). In contrast, the heritability estimates were more similar for RCT, ranging from 0.28 in $\mathrm{DH}$ to 0.45 in DJ.

Genomic correlations between CFR and compositional traits ranged from -0.95 to 0.82 , with standard errors ranging from 0.16 to 0.46 (Table 4). Strong positive correlations were identified between CFR and fat and protein contents. The CFR showed negative relationships with yield and, to some extent, with lactose and citric acid contents (Table 4). For conductivity, $\mathrm{pH}$, and urea, the genomic correlations with CFR were weak and had large standard errors. As for phenotypic correlations, the genomic correlation with RCT between the 2 breeds showed a more complex pattern, ranging from -0.79 to 0.55 , and had higher standard errors. However, yield, fat, and protein reflected the same pattern as observed in the phenotypic correlations. Genomic correlations for RCT and CFR were very different among the breeds: -0.90 (SE 0.19) in DH and 0.06 (SE 0.43) in DJ cows. 

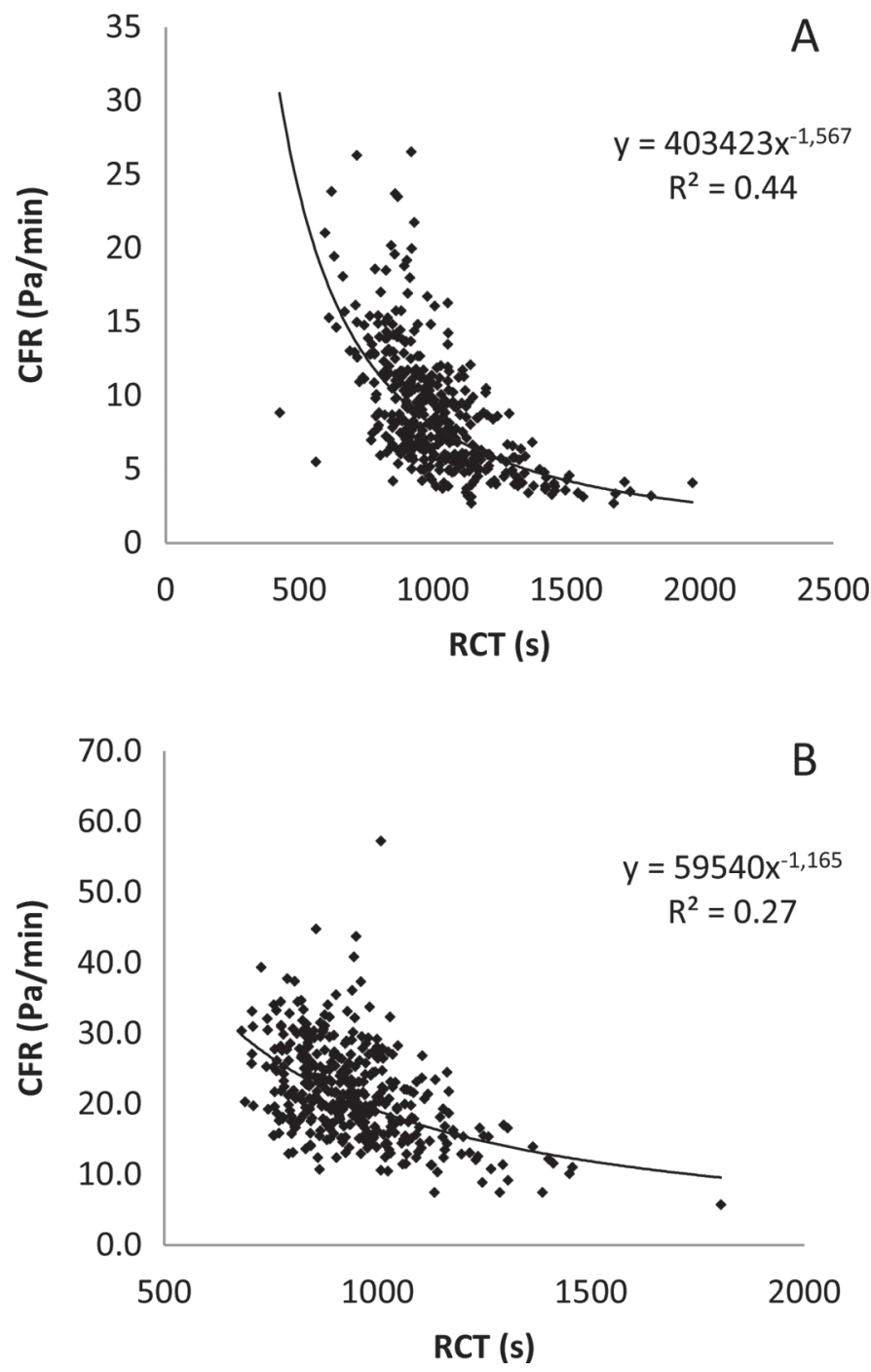

Figure 1. Relationship between rennet coagulation time (RCT) and curd-firming rate (CFR) in Danish Holstein (A) and Danish Jersey (B) cows. Curve indicates the model that best fits the data.

\section{DISCUSSION}

\section{Milk Composition and High SCC}

Danish Jersey cows were characterized by lower yield and higher fat and protein contents, resulting in very different MCP, FA composition, and protein profiles compared with DH cows (Jensen et al., 2012; Poulsen et al., 2012, 2013). Superior rennet-induced MCP in DJ cows has been markedly associated with high frequencies of favorable $\mathrm{CN}$ variants (Poulsen et al., 2013). In a previous study by Poulsen et al. (2013), samples with SCC $>500,000$ cells $/ \mathrm{mL}$ were excluded to ensure that MCP reflected breed differences and not differences in SCC levels among breeds. However, as no sign of clini- cal mastitis was evident, milk from cows with elevated SCC would normally have been transferred to the bulk tank and could affect the quality of the bulk tank milk (Le Maréchal et al., 2011). In Denmark, SCC is used as a general milk quality indicator, and the price of bulk milk with more than 400,000 somatic cells $/ \mathrm{mL}$ is penalized by 4 to $10 \%$ in the payment system (Danish Dairy Board, 2008).

In our study, significant changes in conductivity, lactose, and $\mathrm{pH}$ were observed in milk with high SCC, which is indicative of subclinical mastitis. Lactose is the most important osmotic regulator in milk, and is very constant in most milk samples (Shennan and Peaker, 2000). However, increased influx of ions from blood into the milk due to inflammation of the mammary gland can lead to increased conductivity and decreased lactose content in high SCC milk (Norberg, 2005). A similar relationship between low lactose and high SCC was also observed in a previous study investigating milk metabolite profiles using nuclear magnetic resonance (Sundekilde et al., 2013).

Cows with high SCC had a tendency toward longer RCT and lower CFR, regardless of breed. The slightly impaired MCP of high-SCC milk can be related to increased proteolytic degradation of $\mathrm{CN}$, mainly due to plasmin (Le Maréchal et al., 2011). Wedholm et al. (2006) showed that plasmin was primarily responsible for peptides in low-SCC milk samples, whereas cathepsins and elastases played more prominent proteolytic roles in milk samples from cows with acute clinical mastitis. Therefore, the increased protein content observed in $\mathrm{DH}$ is believed to reflect more concentrated milk due to an increase in the whey protein levels, which is commonly reported in mastitic milk (Le Maréchal et al., 2011). Our data indicate that milk from cows with no clinical signs of mastitis can be significantly different and may cause economic losses for dairies. Fresh milk was analyzed in our study, and longer storage times may impair MCP even more (Somers et al., 2003). In addition to milk composition, SCC was also related to parity, and higher parity affects the susceptibilities of cows to mastitis-causing pathogens.

\section{Correlation Between Coagulation Traits and Milk Composition}

The negative relationship between RCT and CFR has also been reported by others (Ikonen et al., 2004; Hallén et al., 2007; Cassandro et al., 2008; Frederiksen et al., 2011) and is expected, given that the 2 traits represent consecutive steps in the coagulation process. A very marked effect of protein content on CFR was observed in both breeds, whereas the relationship between 
Table 2. Multiple linear regression and test for significance between milk compositional traits and milk coagulation properties [curd-firming rate (CFR) and rennet coagulation time (RCT) $]^{1}$ in Danish Holstein $(\mathrm{DH})$ and Danish Jersey (DJ) cows

\begin{tabular}{|c|c|c|c|c|}
\hline \multirow[b]{2}{*}{ Effect } & \multicolumn{2}{|c|}{ CFR [coefficient (SE)] } & \multicolumn{2}{|c|}{$\mathrm{RCT}[$ coefficient (SE)] } \\
\hline & $\mathrm{DH}$ & DJ & $\mathrm{DH}$ & DJ \\
\hline Protein & $7.74(0.85)^{* * *}$ & $11.36(0.98)^{* * *}$ & $-21.26(47.52)$ & $56.13(23.09)^{*}$ \\
\hline Fat & $0.12(0.30)$ & $0.17(0.41)$ & $-25.16(16.86)$ & $3.66(9.65)$ \\
\hline Lactose & $-0.29(2.27)$ & $8.98(3.26)^{* *}$ & $-126.79(126.30)$ & $-249.88(76.65)^{* *}$ \\
\hline $\mathrm{pH}$ & $5.00(2.91)$ & $14.52(4.52)^{* *}$ & $-492.25(161.80)^{* *}$ & $-316.02(106.34)^{* *}$ \\
\hline Yield & $0.01(0.05)$ & $-0.10(0.12)$ & $0.23(2.94)$ & $4.23(2.80)$ \\
\hline Conductivity & $-1.28(0.78)$ & $0.52(1.03)$ & $41.45(43.24)$ & $9.51(24.13)$ \\
\hline Urea & $0.002(0.003)$ & $-0.003(0.005)$ & $0.08(0.17)$ & $0.30(0.11)^{* *}$ \\
\hline Citric acid & $-6.70(8.53)$ & $59.89(26.24)^{*}$ & $31.98(474.52)$ & $-1943.91(617.17)^{* *}$ \\
\hline Parity 2 and 3 & $0.81(0.40)^{*}$ & $1.30(0.61)^{*}$ & $-9.92(22.05)$ & $-41.43(14.31)^{* *}$ \\
\hline Mid lactation $2^{2}$ & $0.13(0.52)$ & $1.45(0.93)$ & $-21.33(28.77)$ & $26.49(21.81)$ \\
\hline Mid lactation $3^{2}$ & $1.14(0.55)^{*}$ & $1.06(0.94)$ & $-62.17(30.80)^{*}$ & $51.18(22.00)^{*}$ \\
\hline Mid lactation $4^{2}$ & $0.44(1.85)$ & $-0.28(1.33)$ & $34.18(102.88)$ & $133.09(31.41)^{* * *}$ \\
\hline
\end{tabular}

${ }^{1} \mathrm{R}^{2}$ for $\mathrm{CFR} ; \mathrm{DH}=0.30$ and $\mathrm{DJ}=0.34$ and $\mathrm{RCT} ; \mathrm{DH}=0.07$ and $\mathrm{DJ}=0.18$.

${ }^{2}$ Mid lactation $2=\mathrm{d}$ 158-189; mid lactation $3=\mathrm{d}$ 190-220; mid lactation $4=\mathrm{d} 221-252$

${ }^{*} P<0.05,{ }^{* *} P<0.01,{ }^{* * *} P<0.001$.

Table 3. Additive genetic variance $\left(\sigma_{A}^{2}\right)$ and heritability $\left(\mathrm{h}^{2}\right)$ of milk composition and coagulation traits in Danish Holstein (DH) and Danish Jersey (DJ) cows ${ }^{1}$

\begin{tabular}{lccccc}
\hline & \multicolumn{2}{c}{ Danish Jersey } & & \multicolumn{2}{c}{ Danish Holstein } \\
\cline { 2 - 3 } \cline { 5 - 6 } Trait & $\sigma_{A}^{2}$ & $\mathrm{~h}^{2}$ & & $\sigma_{A}^{2}$ & $\mathrm{~h}^{2}$ \\
\hline Yield & 0.408 & $0.088(0.18)$ & & 1.979 & $0.21(0.16)$ \\
SCC & 0.026 & $0.18(0.23)$ & & 0.052 & $0.32(0.17)$ \\
Protein & 0.064 & $0.66(0.29)$ & & 0.024 & $0.40(0.19)$ \\
Fat & 0.302 & $0.38(0.25)$ & & 0.170 & $0.33(0.19)$ \\
Lactose & 0.009 & $0.49(0.32)$ & & 0.008 & $0.49(0.18)$ \\
Conductivity & 0.079 & $0.74(0.31)$ & & 0.036 & $0.30(0.16)$ \\
Urea & $1,320.9$ & $0.80(0.35)$ & & 490.694 & $0.29(0.17)$ \\
Citric acid & 0.0001 & $0.82(0.31)$ & & 0.0003 & $0.59(0.20)$ \\
pH & 0.001 & $0.37(0.26)$ & & 0.001 & $0.35(0.17)$ \\
Rennet coagulation time & $5,381.057$ & $0.45(0.28)$ & & $9,625.857$ & $0.28(0.16)$ \\
Curd-firming rate & 5.877 & $0.15(0.23)$ & & 11.788 & $0.75(0.21)$ \\
\hline
\end{tabular}

${ }^{1} \mathrm{SE}$ of estimates in parentheses.

Table 4. Genomic correlations between milk composition traits and curd-firming rate (CFR) or rennet coagulation time (RCT) in Danish Jersey (DJ) and Danish Holstein (DH) cows ${ }^{1}$

\begin{tabular}{lrrrrr}
\hline & \multicolumn{2}{c}{ Danish Jersey } & & \multicolumn{2}{c}{ Danish Holstein } \\
\cline { 2 - 3 } \cline { 5 - 6 } Trait & \multicolumn{1}{c}{ RCT } & \multicolumn{1}{c}{ CFR } & & \multicolumn{1}{c}{ RCT } & \multicolumn{1}{c}{ CFR } \\
\hline Yield & $-0.05(0.41)$ & $-0.95(0.33)$ & & $0.44(0.43)$ & $-0.51(0.28)$ \\
Protein & $0.55(0.24)$ & $0.70(0.20)$ & & $-0.74(0.38)$ & $0.68(0.16)$ \\
Fat & $0.37(0.31)$ & $0.82(0.27)$ & & $-0.79(0.32)$ & $0.43(0.43)$ \\
Lactose & $-0.41(0.27)$ & $-0.24(0.31)$ & & $0.33(0.36)$ & $-0.27(0.20)$ \\
Conductivity & $0.24(0.27)$ & $-0.24(0.30)$ & & $-0.25(0.46)$ & $0.07(0.26)$ \\
Urea & $0.27(0.25)$ & $-0.15(0.28)$ & & $0.28(0.43)$ & $0.04(0.26)$ \\
Citric acid & $0.25(0.28)$ & $-0.38(0.26)$ & & $0.43(0.31)$ & $-0.32(0.19)$ \\
pH & $-0.41(0.37)$ & $0.31(0.38)$ & & $-0.02(0.36)$ & $0.09(0.24)$ \\
CFR & $0.06(0.43)$ & - & & $-0.90(0.19)$ & - \\
\hline
\end{tabular}

${ }^{1} \mathrm{SE}$ of estimates in parentheses. 
RCT and protein content was less clear. Jõudu et al. (2008) also documented stronger associations between protein content and curd firmness than between protein content and RCT, although curd firmness (expressed as $\mathrm{E}_{30}$ in their study) was not as markedly correlated to protein content as it was in our study.

In contrast to other studies (Tyrisevä et al., 2003; Ikonen et al., 2004; Cassandro et al., 2008; Jõudu et al., 2008), favorable milk coagulation was not associated with low $\mathrm{pH}$ in the present study. Instead, higher $\mathrm{pH}$ was associated with shorter RCT and higher CFR. The result may, to some degree, be related to the $\mathrm{pH}$ adjustment before the coagulation analyses in the present study, which should guarantee optimal and similar conditions for chymosin activity. In a previous study with a small number of cows representing non-, poor, and well-coagulating milk, samples with good MCP had significantly higher native $\mathrm{pH}$ in $\mathrm{DJ}$ but not in DH cows (Jensen et al., 2012). Likewise, samples with good MCP also had higher micellar and total calcium concentrations. Thus, a higher $\mathrm{pH}$ of the original milk sample may be associated with higher levels of micellar calcium phosphate, consistent with Gaucheron (2005). However, other studies showed that total calcium and pH are negatively correlated (Nian et al., 2012), indicating that further studies examining the effects of $\mathrm{pH}$ on calcium distribution in raw milk coagulation are needed.

Citrate may affect the mineral distribution and buffering capacities of milk (Gaucheron, 2005). In a recent study, citrate was associated with impaired MCP (Sundekilde et al., 2011). These findings were not documented in the current study, and higher contents of citric acid were associated with higher CFR and shorter RCT. As with citric acid, increasing lactose contents in DJ had a positive effect on CFR and a negative on RCT. Urea was only weakly associated with RCT in milk from DJ cows. The positive association of lactose on MCP has also been reported by others (Glantz et al., 2010b; Bland et al., 2015), but the mechanisms behind it are still unclear and needs further study.

\section{Genomic Correlation and Heritability Estimates}

The genetic parameters associated with milk production traits discovered in our study were consistent with other reports in the literature (Ikonen et al., 2004; Miglior et al., 2007; Cassandro et al., 2008; Stoop et al., 2008). The sample size in the present study was relatively small, which contributed to large standard errors for the estimates. The DH heritability estimates for yield, fat content, and protein content were 0.21 , 0.33 , and 0.40 , respectively, compared with $0.31,0.39$, and 0.51 , respectively, in a previous study using the same DH data but different animals (Buitenhuis et al., 2013). The large standard errors indicate that these estimates were probably not different. However, heritability estimates and milk properties measured by different analytical methods can differ significantly. For example, in a study by Buitenhuis et al. (2013), the heritability estimate for lactose was 0.17 by NMR; in our study, the estimate was 0.49 by IR when the same samples were used.

The moderate heritability observed for urea in $\mathrm{DH}$ cows was consistent with previous findings (Miglior et al., 2007; Stoop et al., 2007). For MCP, heritability estimates differed most among breeds. In the present study, the observed higher heritability for RCT than for curd firmness in DJ cows was consistent with results from other studies (Ikonen et al., 1999; Cassandro et al., 2008; Cecchinato et al., 2011). However, Vallas et al. (2010) reported higher heritability for curd firmness than for RCT, as was observed for the DH samples in the present study.

The heritability observed for CFR in DH cows was much higher (0.75) than that found in other reports for curd firmness (Ikonen et al., 1999; Cassandro et al., 2008; Vallas et al., 2010; Cecchinato et al., 2011) and contrasted with the generally lower DH heritabilities. These differences may be related to differences in the study population, underlying design, or analytical methods used in the studies. In our study, free oscillation rheometry was used for the coagulation measurements, which can differ from those obtained by other analytical methods. The difference in CFR estimates between DH and DJ cows may also relate to the higher phenotypic variation in $\mathrm{DH} \mathrm{CFR}$, as reported by Bittante et al. (2012). Overall, the data suggest that heritability estimates for curd firmness vary more than RCT estimates. However, by removing the noncoagulating samples, the lower end of the phenotypic distribution was removed, which may also affect the results, despite the low frequency of noncoagulating samples in both cow breeds (see also Poulsen et al., 2013).

Apart from the correlations shown in Table 4, strong genomic correlations were also observed between milk yield and fat content (DH: -0.55 , DJ: -0.97$)$, and fat and protein contents (DH: 0.69, DJ: 0.97), suggesting that these traits are genetically interrelated. The genomic relationship between RCT and CFR was strong in DH cows (-0.90), but not DJ cows (0.06), which further suggests that MCP traits are, to some extent, different in the 2 breeds. Coagulation traits tend to be strongly correlated within breeds (Ikonen et al., 1999; 2004; Penasa et al., 2010; Bonfatti et al., 2011; Cecchinato et al., 2011), suggesting high influences from 
the same genes on MCP. This fact is further reflected in the strong genomic correlation between protein content and MCP traits, which was positive for CFR in $\mathrm{DH}$ and DJ cows, negative for RCT in DH cows, and positive for RCT in DJ cows. The positive genomic correlations between protein content and RCT and CFR in DJ reflect previously reported phenotypic findings (Ikonen et al., 1999; 2004; Vallas et al., 2010). Oloffs et al. (1992) did not document a genetic correlation between protein content and MCP, but showed that higher casein content was genetically related to RCT and curd firmness.

Protein content and composition have strong genetic influences on coagulation traits, as documented in several studies showing strong relationships between $\mathrm{CN}$ genotypes and RCT, CFR, or curd firmness (Jõudu et al., 2007; Penasa et al., 2010; Poulsen et al., 2013). This fact is further related to genetic correlations between the relative contents of whey and $\mathrm{CN}$ proteins and protein percentages; in particular, the relative concentrations of $\kappa-\mathrm{CN}$ and protein show a strong positive genetic correlation, whereas $\alpha-\mathrm{LA}$ and $\alpha_{\mathrm{S1}}$-CN show strong negative correlations with each other (Schopen et al., 2009). In a recent study from Swedish Red cows, a marked positive genetic correlation were observed between $\kappa-\mathrm{CN}$ concentration and gel strength, whereas the genetic correlation between protein content and gel strength was weak (Gustavsson et al., 2014). Several studies showed that favorable MCP were genetically associated with low pH (Oloffs et al., 1992; Ikonen et al., 1999; 2004; Cassandro et al., 2008). This result was not validated in the current study, perhaps because $\mathrm{pH}$ adjustment was done before the MCP measurements.

\section{CONCLUSIONS}

This study has documented variations in major milk components and their correlations with MCP including milk with high SCC. Risk factors associated with poor coagulation seem to be related to protein content, but conductivity, lactose, and $\mathrm{pH}$ may also play important roles. Particularly, the effects of milk $\mathrm{pH}$ on micelle stability and MCP should be more closely examined. The MCP traits in DJ and DH cows are heritable, and selective breeding can therefore be used to alter these traits in the breeding populations. However, the study also documents that the genetic basis of the MCP traits is not the same in the 2 breeds. In $\mathrm{DH}$ cows, genetic selection for higher CFR will result in shorter RCT, whereas selection for higher CFR in DJ will not affect $\mathrm{RCT}$, but rather increase fat and protein content and lower yield. The results, therefore, clearly document the risk of transferring results obtained in one breed to another breed.

\section{ACKNOWLEDGMENTS}

This work was supported by grants from Arla Foods (Viby J, Denmark), the Danish Cattle Federation (Aarhus, Denmark), the Danish Strategic Research Council (Copenhagen K, Denmark), Aarhus University (Aarhus, Denmark), and the Milk Levy Fund (Aarhus N, Denmark) through the "Milk Genomics" and "Phenotypic and genetic markers for specific milk quality parameters" projects. The Danish sampling and analysis team at the Danish-Swedish Milk Genomics Initiative is gratefully acknowledged for excellent technical assistance.

\section{REFERENCES}

Bittante, G., M. Penasa, and A. Cecchinato. 2012. Invited review: Genetics and modeling of milk coagulation properties. J. Dairy Sci. 95:6843-6870

Bland, J. H., A. S. Grandison, and C. C. Fagan. 2015. Evaluation of milk compositional variables on coagulation properties using partial least squares. J. Dairy Res. 82:8-14.

Bonfatti, V., A. Cecchinato, L. Gallo, A. Blasco, and P. Carnier. 2011. Genetic analysis of detailed milk protein composition and coagulation properties in Simmental cattle. J. Dairy Sci. 94:5183-5193.

Bonfatti, V., G. Chiarot, and P. Carnier. 2014. Glycosylation of $\kappa$-casein: Genetic and nongenetic variation and effects on rennet coagulation properties of milk. J. Dairy Sci. 97:1961-1969.

Buitenhuis, A. J., U. K. Sundekilde, N. A. Poulsen, H. C. Bertram, L. B. Larsen, and P. Sørensen. 2013. Estimation of genetic parameters and detection of quantitative trait loci for metabolites in Danish Holstein milk. J. Dairy Sci. 96:3285-3295.

Cassandro, M., A. Comin, M. Ojala, R. Dal Zotto, M. De Marchi, L. Gallo, P. Carnier, and B. Bittante. 2008. Genetic parameters of milk coagulation properties and their relationships with milk yield and quality traits in Italian Holstein cows. J. Dairy Sci. 91:371-376.

Cecchinato, A., M. Penasa, M. De Marchi, L. Gallo, G. Bittante, and P. Carnier. 2011. Genetic parameters of coagulation properties, milk yield, quality and acidity estimated using coagulating and noncoagulating milk information in Brown Swiss and HolsteinFriesian cows. J. Dairy Sci. 94:4205-4213.

Danish Agricultural and Food Council. 2012. Dairy Statistics. Danish Agricultural \& Food Council, Copenhagen, Denmark.

Danish Dairy Board. 2008. Mejeriforeningens Afregningsmodel. Danish Dairy Board, Aarhus, Denmark.

Frederiksen, P. D., M. Hammershøj, M. Bakman, P. N. Andersen, J. B. Andersen, K. B. Qvist, and L. B. Larsen. 2011. Variations in coagulation properties of cheese milk from three Danish dairy breeds as determined by a new free oscillation rheometry-based method. Dairy Sci. Technol. 91:309-321.

Gaucheron, F. 2005. The minerals of milk. Reprod. Nutr. Dev. 45:473-483.

Glantz, M., T. G. Devold, G. E. Vegarud, H. Lindmark Månsson, H. Stålhammar, and M. Paulsson. 2010b. Importance of casein micelle size and milk composition for milk gelation. J. Dairy Sci. 93:1444-1451.

Glantz, M., A. Håkansson, H. Lindmark Månsson, M. Paulsson, and L. Nilsson. 2010a. Revealing the size, conformation, and shape of casein micelles and aggregates with asymmetrical flow fieldflow fractionation and multiangle light scattering. Langmuir 26:12585-12591.

Gustavsson, F., M. Glantz, A. J. Buitenhuis, H. Lindmark-Månsson, H. Stålhammar, A. Andrén, and M. Paulsson. 2014. Factors influencing chymosin-induced gelation of milk from individual dairy cows: Major effects of casein micelle size and calcium. Int. Dairy J. 39:201-208. http://dx.doi.org/10.1016/j.idairyj.2014.06.011. 
Hallén, E., T. Allmere, J. Näslund, A. Andrén, and A. Lundén. 2007. Effect of genetic polymorphism of milk proteins on rheology of chymosin-induced milk gels. Int. Dairy J. 17:791-799.

Hallén, E., A. Lunden, A. M. Tyrisevä, M. Westerkind, and A. Andrén. 2010. Composition of poorly and non-coagulating milk and effect of calcium addition. J. Dairy Res. 77:398-403.

Ikonen, T., K. Ahlfors, R. Kempe, M. Ojala, and O. Ruottinen. 1999. Genetic parameters for the milk coagulation properties and prevalence of noncoagulating milk in Finnish dairy cows. J. Dairy Sci. 82:205-214.

Ikonen, T., S. Morri, A. M. Tyriseva, O. Ruottinen, and M. Ojala. 2004. Genetic and phenotypic correlations between milk coagulation properties, milk production traits, somatic cell count, casein content and $\mathrm{pH}$ of milk. J. Dairy Sci. 87:458-467.

Jensen, H. B., N. A. Poulsen, K. K. Andersen, M. Hammershøj, H. D. Poulsen, and L. B. Larsen. 2012. Distinct composition of bovine milk from Jersey and Holstein-Friesian cows with good, poor or non-coagulation properties as reflected in protein genetic variants and isoforms. J. Dairy Sci. 95:6905-6917. http://dx.doi. $\operatorname{org} / 10.3168 / \mathrm{jds} .2012-5675$.

Jõudu, I., M. Henno, T. Kaart, T. Püssa, and O. Kärt. 2008. The effect of milk protein contents on the rennet coagulation properties of milk from individual dairy cows. Int. Dairy J. 18:964-967.

Jõudu, I., M. Henno, S. Värv, T. Kaart, O. Kärt, and K. Kalamees. 2007. Milk protein genotypes and milk coagulation properties of Estonian native cattle. Agric. Food Sci. 16:222-231.

Le Maréchal, C., R. Thiéry, E. Vautor, and Y. Le Loir. 2011. Mastitis impact on technological properties of milk and quality of milk products-A review. Dairy Sci. Technol. 91:247-282.

Liu, Y., X. Qin, X. Z. H. Song, H. Y. Jiang, Y. F. Shen, K. J. Durbin, S. Lien, M. P. Kent, M. Sodeland, Y. R. Ren, L. Zhang, E. Sodergren, P. Havlak, K. C. Worley, G. M. Weinstock, and R. A. Gibbs. 2009. Bos taurus genome assembly. BMC Genomics 10:180.

Madsen, P., and J. Jensen. 2007. A User's Guide to DMU: A Package for Analysing Multivariate Mixed Models. Ver. 6, rel. 4.7. Aarhus University, Tjele, Denmark.

Miglior, F., A. Sewalem, J. Jamrozik, J. Bohmanova, D. M. Lefebvre, and R. K. Moore. 2007. Genetic analysis of milk urea nitrogen and lactose and their relationship with other production traits in Canadian Holstein cattle. J. Dairy Sci. 90:2468-2479.

Nian, Y., B. Y. Chen, P. Aikman, A. Grandison, and M. Lewis. 2012 Naturally occurring variations in milk $\mathrm{pH}$ and ionic calcium and their effects on some properties and processing characteristics of milk. Int. J. Dairy Technol. 65:490-497.

Norberg, E. 2005. Electrical conductivity of milk as a phenotypic and genetic indicator of bovine mastitis: A review. Livest. Prod. Sci. 30:239-249.

Oloffs, K., H. Shulte-Coerne, K. Pabst, and H. O. Gravert. 1992. Die bedeutung der proteinvarianten für genetische unterschiede in der käsereitauglichkeit der milch. Zuchtungskunde 64:20-26.

Palmquist, D. L., A. D. Beaulieu, and D. M. Barbano. 1993. Feed and animal factors influencing milk fat composition. J. Dairy Sci. $76: 1753-1771$.

Penasa, M., M. Cassandro, D. Pretto, M. De Marchi, A. Comin, S. Chessa, R. Dal Zotto, and G. Bittante. 2010. Influence of composite casein genotypes on additive genetic variation of milk production traits and coagulation properties in Holstein-Friesian cows. J. Dairy Sci. 93:3346-3349.
Poulsen, N. A., H. P. Betelsen, H. B. Jensen, F. Gustavsson, M. Glantz, H. L. Månsson, A. Andrén, M. Paulsson, C. Bendixen, A. J. Buitenhuis, and L. B. Larsen. 2013. The occurrence of noncoagulating milk and the association of bovine milk coagulation properties with genetic variants of the caseins in 3 Scandinavian breeds. J. Dairy Sci. 96:4830-4842.

Poulsen, N. A., F. Gustavsson, M. Glantz, M. Paulsson, L. B. Larsen, and M. K. Larsen. 2012. The influence of feed and herd on fatty acid composition in 3 dairy breeds (Danish Holstein, Danish Jersey, and Swedish Red). J. Dairy Sci. 95:6362-6371.

Schopen, G. C. B., J. M. L. Heck, H. Bovenhuis, M. H. P. W. Visker, H. J. F. van Valenberg, and J. A. M. van Arendonk. 2009. Genetic parameters for major milk proteins in Dutch Holstein-Friesians. J. Dairy Sci. 92:1182-1191.

Shennan, D. B., and M. Peaker. 2000. Transport of milk constituents by the mammary gland. Physiol. Rev. 80:925-951.

Somers, J. M., B. O'Brien, W. J. Meaney, and A. L. Kelly. 2003. Heterogeneity of proteolytic enzyme activities in milk samples of different somatic cell count. J. Dairy Res. 70:45-50.

Stoop, W. M., H. Bovenhuis, and J. A. M. Arendonk. 2007. Genetic parameters for milk urea nitrogen in relation to milk production traits. J. Dairy Sci. 90:1981-1986.

Stoop, W. M., J. A. M. van Arendonk, J. M. L. Heck, H. J. F. van Valenberg, and H. Bovenhuis. 2008. Genetic parameters for major milk fatty acids and milk production traits of Dutch HolsteinFriesians. J. Dairy Sci. 91:385-394.

Sundekilde, U. K., P. D. Frederiksen, M. R. Clausen, L. B. Larsen, and H. C. Bertram. 2011. Relationship between metabolite profile and technological properties of bovine milk from two dairy breeds elucidated by NMR-based metabolomics. J. Agric. Food Chem. 59:7360-7367.

Sundekilde, U. K., N. A. Poulsen, L. B. Larsen, and H. C. Bertram. 2013. Nuclear magnetic resonance metabonomics reveals strong association between milk metabolites and somatic cell count in bovine milk. J. Dairy Sci. 96:290-299.

Teo, Y. Y., M. Inouye, K. S. Small, R. Gwilliam, P. Deloukas, D. P. Kwiatkowski, and T. G. Clark. 2007. A genotype calling algorithm for the Illumina BeadArray platform. Bioinformatics 23:27412746.

Tyrisevä, A. M., T. Ikonen, and M. Ojala. 2003. Repeatability estimates for milk coagulation traits and non-coagulation of milk in Finnish Ayrshire cows. J. Dairy Res. 70:91-98

Vallas, M., H. Bovenhuis, T. Kaart, K. Pärna, H. Kiiman, and E. Pärna. 2010. Genetic parameters for milk coagulation properties in Estonian Holstein cows. J. Dairy Sci. 93:3789-3796.

Van Tassell, C. P., T. P. Smith, L. K. Matukumalli, J. F. Taylor, R D. Schnabel, C. T. Lawley, C. D. Haudenschild, S. S. Moore, W. C. Warren, and T. S. Sonstegard. 2008. SNP discovery and allele frequency estimation by deep sequencing of reduced representation libraries. Nat. Methods 5:247-252.

VanRaden, P. M. 2008. Efficient methods to compute genomic predictions. J. Dairy Sci. 91:4414-4423.

Wedholm, A., L. B. Larsen, H. Lindmark-Mansson, A. H. Karlsson, and A. Andrén. 2006. Effect of protein composition on the cheesemaking properties of milk from individual dairy cows. J. Dairy Sci. 89:3296-3305. 